Journal of Jazz Studies, vol. 10, no. 2, pp. 95-118 (Winter 2014-2015)

\title{
Dig - It: The Musical Life of Ted Brown
}

\author{
Marian Jago
}

My only ambition was to play jazz; I had no interest in trying to make a living playing commercial music-Ted Brown ${ }^{1}$

Ted is to me one of the few real improvisers around. He starts right from scratch, and begins improvising from the first note. If it doesn't come off, it sounds very sketchy. If it does, it's just beautiful—Lee Konitz ${ }^{2}$

\section{INTRODUCTION}

The field of jazz scholarship has paid surprisingly little attention to the jazz practices, pedagogical methods, and lineal traditions associated with pianist and educator Lennie Tristano. On Tristano himself there exist only a handful of scholarly articles (Jago 2011, 2013, 2015) and two books (Ind 2005, Shim 2007). ${ }^{3}$ Even Paul Berliner's landmark Thinking in Jazz (Berliner 1994), a volume concerned with the ways and means by which jazz is taught and learned does not devote space to an examination of Tristano, who was one of the first to engage in a methodological approach to jazz pedagogy. ${ }^{4}$ Tristano's most famous students - tenor saxophonist Warne Marsh and alto saxophonist Lee Konitz-have also received little scholarly attention. There are to date two books on Marsh, the first of which, An Unsung Cat: The Life and Music of Warne Marsh, is a comprehensive biography written by a former student

${ }^{1}$ Ted Brown January 17, 2009.

${ }^{2}$ In Nat Hentoff (1956).

${ }^{3}$ There is also a 1978 music education thesis (McKinney 1978) which though likely remarkable for its time, lacks depth and is quite rudimentary presentation of Tristano and his methods. Eunmi Shim's Lennie Tristano: His Life in Music (2007) is a well researched and valuable volume, whereas Jazz Visions: Lennie Tristano and His Legacy (2005), written by former Tristano bassist Peter Ind, is less a useful and at times frustrating work which more often serves as biography of Ind rather than an exposition of Tristano.

${ }^{4}$ Berliner's work does at times quote Lee Konitz, which makes Tristano's exclusion even more puzzling. 
(Chamberlain 2000), while the second, Out of Nowhere: The Musical Life of Warne Marsh, is a "fictional biography" written in the first-person (Cornelius 2002). Uniquely, Marsh has also been the topic of one doctoral dissertation (Petrucelli 2012) and one master's thesis (Emerzian 2002). ${ }^{5}$ Alto saxophonist Lee Konitz, who possesses one of the most substantial recording catalogues in jazz and is, at the age of eighty-seven, still remarkably active on the festival and club scene, has received astonishingly little attention given his accessibility to interested scholars. In addition to one scholarly article (Jago 2011), Konitz has been the focus of a single book, Andy Hamilton's Lee Konitz: Conversations on the Improviser's Art (Hamilton 2007), which, though an engaging work that utilizes the voice of the artist in a vital and unique way, fails to provide much detailed discussion of the musical process itself. ${ }^{6}$ On other members of the Tristano "school" there is essentially nothing. ${ }^{7}$

Lack of scholarly attention to the players of this particular school may stem from a number of reasons, chief among them the processes of canon formation. There remains a tendency in jazz scholarship to examine and re-examine the work of larger figures within the canon (Parker, Coltrane, Davis, Henderson, et al.) rather than to undertake original historical, ethnographic, and musicological research into hitherto un-, or under-documented artists. The analytical traditions common to much of musicology have been widely adopted by the area of jazz studies, a grafting which has led to an emphasis upon transcription and analysis of music "on the page," rather than in the field. This (over) emphasis upon transcription and analysis within academic writing on jazz is perhaps also tied to the fact that the vast majority of those pursuing graduate work in jazz studies come from a performance background and therefore lack experience with alternate modes of inquiry which might be borrowed from the fields of ethnomusicology and popular music studies. ${ }^{8}$ Recent work by the likes of Ake (2010, 2012), Atkins (2001, 2003), Jackson (2012), McKay (2005), Stewart (2007), and others are beginning to expand the discourse on jazz to include aspects of performative process, as well as concepts of community,

\footnotetext{
${ }^{5}$ The dissertation is a work of musical analysis devoted to one particular recording and the master's thesis examines Marsh's influence upon saxophonist Mark Turner.

${ }^{6}$ Particularly when it comes to discussing approaches to playing and practicing that are uniquely tied to the saxophone.

${ }^{7}$ Ellen Johnson's Jazz Child: A Portrait of Sheila Jordan (2014) is a recent exception. Though Jordan herself identifies most strongly with Charlie Parker, she spent some time as a student of Tristano's at his Manhattan studio, and was profoundly affected by her experiences there.

${ }^{8}$ The chord/scale approach of many performance programs no doubt exacerbates this tendency toward transcription and analysis at the graduate level.
} 
politics, lived experience, scenes, trans-national processes, and the various ways in which jazz comes to hold meaning, yet even a cursory search of recently completed dissertations in jazz studies still reveals a lingering emphasis upon transcription and analysis. This privileging of discographical output serves to diminish the importance of localized musical practice, involvement, and discourse. The staggering majority of jazz artists (even very accomplished ones) live out whole careers in relative obscurity, and the restrictive nature of canon formation within the field exacerbates this effect. ${ }^{9}$

The music of Tristano and his associates is also difficult to categorize, and does not conveniently locate itself within the historical and stylistic divisions common to much of jazz discourse (textbooks, documentaries, box sets, etc.). Tristano was perhaps the first to record free jazz (1949), ${ }^{10}$ was one of the first to experiment with extended studio techniques in jazz, ${ }^{11}$ and played an angular, eighth-note driven style which held much in common with bebop, yet the music of Tristano and his associates is also frequently (and I feel problematically) filed under the label cool jazz. Cool jazz has historically been associated with a white, inauthentic, effeminate, non-swinging style of jazz, and these long standing negative associations with cool jazz may have contributed to the lack of scholarly interest in the music and musical lives of Tristano, Marsh, Konitz, and others. ${ }^{12}$

Nonetheless, nearly every major jazz critic has weighed in at some time or another with an opinion on Tristano and his methods. In particular, the perennially reprinted The Masters of BeBop (Gitler 1966) provides an excellent examination of Tristano, Konitz and Marsh which also serves to situate them within the larger bebop tradition. Contemporary jazz publications such as Metronome and DownBeat featured articles on both Tristano and his students regularly, and often provided Tristano with the opportunity to voice his

\footnotetext{
${ }^{9}$ Ethnomusicological traditions of writing about common, marginalized, insular and otherwise poorly represented groups may provide useful models for those wishing to explore relatively uncharted territory in the field of jazz scholarship. Ethnomusicology's concern with the nature of individual experience(s) of music (and for the associated fieldwork) could prove a vital resource for jazz, an area which is seeing the architects of its music pass on at an alarming rate. The realities of these musical lives and experiences are as important to an understanding of jazz and jazz practices as are examinations of musical materials.

${ }^{10}$ Free improvisation had been a nightly part of his group's performances for nearly a year before the ground breaking Capitol recordings in 1949.

${ }^{11}$ Tristano was one of the first in jazz to make use of over-dubbing, multi-tracking, etc. see Jago 2013.

${ }^{12}$ Pianist Sal Mosca, bassists Peter Ind and Sonny Dallas, trumpeter Don Ferrera, et al.
} 
musical opinions. ${ }^{13}$ Recently, the fame of tenor player Mark Turner (who is vocal in his appreciation for the Tristano school in general and Warne Marsh in particular), the Shim and Hamilton publications, recent crowd-funding activities in support of an up-coming documentary film on Warne Marsh, ${ }^{14}$ and the continued performance activity of both Lee Konitz and Ted Brown has resulted in a minor upswell of interest in this vital yet under-regarded school of jazz playing. ${ }^{15}$

What is often overlooked in all of the heated debate over Tristano's music, personal eccentricities, and his whiteness, is that Tristano was a teacher by design rather than by default. Teaching was not assumed simply as a means to an end-a way to supplement performance activities which were prioritizedbut was considered an end in and of itself. Tristano taught jazz through a structured approach which denied mythology for hard work; improvising became not something a person either had or didn't, but something that could be developed and nurtured through discipline and practice. Tristano both formalized and universalized the long-standing tradition of ad hoc apprenticeships in jazz, and opened tutelage in jazz improvisation to anyone with the commitment to study. At the same time, Tristano's studio was markedly different from institutional approaches to jazz education (both historical and contemporary), as his methodology, though rooted in the acquisition of key skills and approaches, was tailored to each student's inclinations and abilities. ${ }^{16}$

Improvisation was the paramount focus of Tristano's approach, and as such, musical materials (scales, chords, etc.) were regarded as a means to an end, rather than an end in themselves. The process of study under Tristano was painstaking and time consuming, and aimed toward obtaining complete

\footnotetext{
${ }^{13}$ These discussions have often become quite heated. Tristano's views upon the role of the rhythm section, his use of tape splicing, his teaching methodology and his identity as a white jazz musician have frequently been flashpoints for passionate debate. For example see DownBeat, May 16, 1956, 11-12, 42 and DownBeat, June 13, 1956, 4.

${ }^{14}$ A project undertaken by his son, $\mathrm{KC}$.

${ }^{15}$ See also Lee Konitz and Ted Brown's respective recording activity. Lee Konitz was as well the recipient of the NEA's Jazz Masters award in 2009. Note also the recent event hosted by the Los Angeles Jazz Institute "Something Cool: Celebrating the Sounds of the Cool School" (October 2014) which included a variety panels on Tristano, Konitz, and Marsh, along with performances by Konitz and Brown. It is worth noting perhaps that this cool jazz conference included panels on Lester Young, Wardell Grey, Dexter Gordon, and Tadd Dameron.

${ }^{16}$ Konitz, for example, has often remarked to me that his relationship with Tristano was very different from Warne Marsh's. Tristano's approach with Konitz was in getting him to play intuitively and in keeping with his melodic pre-disposition, whereas Tristano's approach with Marsh reflected Marsh's prior experience on piano and considerable interest in harmony.
} 
command of the instrument and of the musical material in order that the musician could play truly unconsciously; improvising from note-to-note in the moment without resort to a preconceived vocabulary of stock phrases or licks. ${ }^{17}$ As pianist Ethan Iverson notes:

It wasn't enough to figure out how to get to any note on any chord; Tristano wanted to find those notes in the moment, without pre-imagined patterns. ... The process worked: in comparison to a good Tristano, Warne Marsh, or Lee Konitz solo, any solo of Charlie Parker or Bud Powell has much more passage work or "licks" that aren't really improvised, but are simply the language of bebop. (Iverson 2008)

Tristano required that his students commit to a minimum of one year's unbroken study, a condition which prevented students from taking work in touring orchestras or ensembles. ${ }^{18}$ Instead, Tristano encouraged many of his students to take non-musical day jobs which provided the financial security and stable schedule required to support a concentrated period of musical study. A key feature of Tristano's pedagogy was its use of imaginative techniques for musical practice, an approach which recognized the limitations on instrumental practice faced by many living in urban environments, and by those who were unable to dedicate themselves full-time to music. ${ }^{19}$ By all accounts a demanding and thoroughly committed teacher, Tristano's approach was both

\footnotetext{
${ }^{17}$ The incredulity and even occasional hostility which has met some of these ideas at master classes given by Konitz (Humber College and University of Toronto 2005 \& Roberto's Woodwinds NYC 2007) and Don Palmer (a former student of Tristano and Konitz who teaches using their methodologies) bears this out, as does my own experience of this way of learning in comparison with the curriculum at a major jazz college that I briefly attended.

${ }^{18}$ The process of interviewing prospective students and requiring a year's commitment seems to have been a hallmark only of Tristano's early teaching efforts. Though he began teaching in the 1940s, he is best know for the years 1951-1956, during which time he operated a studio at 317 E. 32nd Street. After the closure of the studio, his teaching activity was based out of his home in Queens. At this point it seems that conditions surrounding lessons were relaxed somewhat. Canadian saxophonist Don Palmer, who took lessons with Tristano between 19631965, was not subjected to an interview (though he was already a student of Konitz', which might be relevant) and did not have to commit to a solid year's worth of lessons. That said, Palmer stopped studying with Tristano as he began to be employed by touring ensembles with a frequency that made studying impractical.

${ }^{19}$ Those interested in these mental approaches should see the author's "Jedi Mind Tricks: Lennie Tristano \& Mental Approaches for the Practice of Jazz Improvisation" which is slated for publication in an upcoming issue of Jazz Research Journal.
} 
so revolutionary and so practical that he never lacked for students, at times carrying a waiting list (Shim 2007). ${ }^{20}$

Tristano had hundreds, if not thousands of students over the years, many of whom went on to lead remarkable careers, though with such little attention paid to the likes of Tristano, Marsh and Konitz, it goes nearly without saying that popular regard for these musicians is almost nonexistent. ${ }^{21}$ Fame however, is a faulty barometer for artistic achievement, and the lives and work of these lesser-known players can provide great insight into the nature of jazz improvisation, and to ways in which the pedagogical methods of the Tristano school were regularly enacted.

\section{TED BROWN}

I'd been aware of Ted Brown's playing for several years, having first heard him on Warne Marsh's Jazz of Two Cities (Imperial 1956) recording, and later on a few albums with Lee Konitz. While working at a record store in Toronto, I managed to obtain several albums that Brown had recorded in the mid-80s for a European label, and which were, in the days before iTunes, rather difficult to find. In 2004 I began studying with Lee Konitz in New York, and was at a performance of his New Nonet at the Jazz Standard when I recognized Ted Brown in the audience. I arranged an introduction, and we spent some time talking. Later that month I heard Brown play with Konitz at the Jazz Gallery and we shared further conversation. I voiced an interest in the lines that he had written while studying with Tristano, and he later provided me with parts for all of his compositions, as well as with several pages of notes he taken in the course of his studies with Tristano. As I embarked upon a study of his music, ${ }^{22}$ we kept up a series of personal exchanges via e-mail, letter, and in-person on my frequent trips to New York. Those conversations and my concurrent

\footnotetext{
${ }^{20}$ Tristano's studio at 317 E. 32nd Street in Manhattan also hosted many established artists who were interested in his music and / or teaching activities. Such notables as Charlie Parker, Charles Mingus, Max Roach, Roy Haynes, Stan Getz, and Leonard Bernstein were regular visitors.

${ }^{21}$ For example Sal Mosca, Bill Russo, Connie Crothers, Ted Brown, JoAnne Brackeen, Don Ferrera, Jimmy Halperin, Sheila Jordan, et al. Artists such as Dave Liebman, Phil Woods, \& Alan Broadbent would be a notable exceptions who have indeed received considerable popular and critical attention.

${ }^{22}$ Learning his compositions and some solos, and tracking down his other recordings.
} 
research into Tristano and Lee Konitz ${ }^{23}$ led to this paper, which I offer as a preliminary musical biography of Ted Brown, and as gesture toward the sort of ethnographic fieldwork with which I feel jazz studies should more actively engage. ${ }^{24}$

Ted Brown was born into a musical family in Rochester, New York on December 1, 1927. He displayed an interest in music from an early age and started studies on banjo at age 6, moving to the violin at age 10 and finally to clarinet and tenor saxophone when he entered high school in 1941. In 1942, following his father's enlistment in the Navy Air Corps, the Browns moved to Southern California.

My father led a jazz band in the late twenties and early thirties in Rochester, N.Y. He played banjo primarily but also violin and saxophone at times. He transcribed all the parts from a few Red Nichols and His Five Pennies records and used them as some of the arrangements for his band. His father and brother also played saxophone and both also played in the band. My father started teaching me to read music on his banjo when I was 6 years old. He also had a 4-string tenor guitar which fingered like a banjo so I played that for a while because I liked the sound better. When I was in the $6^{\text {th }}$ grade $\ldots$ around 10 years old ... I became interested in the violin. My father started me off with a few lessons and then I joined a weekly group class in school which was taught by a young lady from the Eastman School of Music. I played violin in the orchestra at school through the $8^{\text {th }}$ grade. When I started High School in the $9^{\text {th }}$ grade $\ldots$ 1941, age 14 ... I wanted to play in the small groups which played for dances on Fridays, so I switched to clarinet and tenor saxophone, taking lessons from my uncle. (Brown January 17, 2009)

As with many jazz musicians, early exposure to the music came through records and radio. The era of the dance band was at its height, and the hit tunes of the day played incessantly on radio, many of which would form the standard repertoire for jazz improvisation. As Ted's father was himself a jazz musician, musical resources were widely available and encouraged. It's clear

\footnotetext{
${ }^{23}$ My studies with Konitz formed a large part of my master's MRP, "Musical Koryu: The Pedagogical Practices \& Lineal Traditions of Lennie Tristano \& Lee Konitz," portions of which have been published or are forthcoming in a variety of journals.

${ }^{24}$ In 2008 when I began talking with Ted Brown, he commented to me that it was the first time that anyone had asked him about his own musical life and experiences, and not simply about his experience of Tristano, Marsh, or Konitz. This introductory work will hopefully be followed by a more detailed examination of Ted Brown's music, whether by myself or another scholar.
} 
that Brown's father was a seminal influence on his musical development, and many of the techniques which were passed on in these early lessons would prepare Brown well for his later studies with Tristano.

When I was in the 10th and 11th grades my father insisted that I learn the melodies to some of the major tunes. He played his 4-string guitar along with me and encouraged me to fill out some of the phrases with my own little melodies. We never discussed chord changes ... just melodies. He taught me how to copy jazz solos from records and write them out ... first a couple on clarinet and then he helped me transcribe Coleman Hawkins' solo on "Body and Soul.” (Brown January 17, 2009)

Not originally planning on a career in music, Brown's initial ambition was to be an aeronautical engineer, and he recalls having his practice time severely curtailed in the later years of high school as he studied math and science and concentrated on his grades. ${ }^{25}$ By the end of high school however, his plans had changed.

I changed my mind about a month before I graduated in 1945 when I got a nice gig playing in a big band Friday and Saturday nights in Huntington Beach, CA. I joined the musicians union in L.A. and spent the summer rehearsing with that same bandleader (Hal Brooks) who had moved to Hollywood and was using The Hollywood Canteen ${ }^{26}$ as a place to rehearse during the day. He also got me on a few gigs with the USO touring Army bases. (Brown October 6, 2008)

After graduating high school in 1945, Brown worked through the summer and fall touring American army bases with a USO band. On the road in Texas as he turned 18, Brown received his draft notice and by February of 1946 was stationed at Camp Lee, Virginia as part of an army post band. In this perhaps unlikely setting, new personal and musical influences would prompt the first significant steps towards his development as a jazz artist.

In 1946 Brown was still heavily influenced by tenor player Coleman Hawkins, and it was not until his time in the army that he spent much time listening to Lester Young, a player whose sound, lyricism, and rhythmic sensibility would have a profound affect upon the players of the Tristano

\footnotetext{
${ }^{25}$ This early interest in the sciences may have impacted Ted's later decision to enter the field of IT when computer programming was in its infancy.

${ }^{26}$ Though their paths did not cross at this time, Warne Marsh was also active in USO bands in California and his first recordings are as part of the Canteen Kids, a group that performed regularly at the Hollywood Canteen, the most famous of all USO service clubs.
} 
school. Bebop was at its creative height, and Brown spent many hours listening to Charlie Parker and transcribing his solos, notably "Ko-Ko," Parker's treatment of Ray Noble's "Cherokee" (Brown January 17, 2009). On a weekend pass in 1946, Ted visited New York for the first time.

While I was still in the Army in 1946 I visited New York and 52nd Street. I saw Lester Young for the first time and he really impressed me. When he finished his set he walked out of the club with his horn, no case, and went to another club down the street where he sat in. My friend and I followed him and really enjoyed listening to him. I also saw tenor player Alan Eager sitting in at one of the clubs. He was my age and was also influenced by Pres ... so for the next couple years I had in mind that I would someday like to do what he was doing on 52nd Street. (Brown January 17,2009 )

A further influence during these years was tenor player Dexter Gordon.

We were also listening to Dexter Gordon and Gene Ammons. Billy Eckstein had a fantastic big band in the mid forties. Dexter and Gene were on that band which also included at various times Bird, $\mathrm{Diz}^{27}$ and Art Blakey with Billy Eckstein playing valve trombone, fronting the band and singing. They had a swinging record out called "Lonesome Lover Blues" and Dexter and Gene traded some great eight bar phrases (first time I ever heard that). Dexter Gordon was actually one of the first tenor players to be heavily influenced by both Pres and Bird. He was a big influence on many other tenor players, including myself, because as great as Pres was, tenor players could not just ignore Bird. Dexter solved that problem as sort of a transitional figure. (Brown January 17, 2009)

While stationed at Camp Lee, Brown also made several personal connections which would have a profound affect on the direction of his life and music. Brown became close friends with a clarinetist named Bob Stacy who was from Chicago, and who had taken several lessons with Lennie Tristano. ${ }^{28}$ Though Brown had no immediate desire to study with Tristano, it would be Stacy who would eventually introduce them. Also at stationed at Camp Lee was trumpeter Don Ferrara, ${ }^{29}$ who had also studied with Tristano before being drafted and was continuing his studies through mail correspondence during his

\footnotetext{
${ }^{27}$ Charlie Parker and Dizzy Gillespie, respectively.

${ }^{28}$ Tristano was from Chicago and began his playing and teaching career there.

${ }^{29}$ Ferrara was long associated with the Tristano school, and would go on to record with Lee Konitz.
} 
enlistment, ${ }^{30}$ and tenor saxophonist Warne Marsh. ${ }^{31}$ United by their burgeoning interest in jazz, Marsh, Brown, Ferrara, Stacy and others would regularly meet to listen to recordings and play together. ${ }^{32}$ Through Don Ferrara and Bob Stacy, Marsh was introduced to the ideas of Tristano, and began studying with him during the last six months of his enlistment.

Stacy, Marsh, Ferrara, and Brown were particularly impressed by Tristano's thoroughness in ensuring that his students acquired complete command of their instruments and facility in all twelve keys. In today's culture of institutionalized jazz education it seems obvious that a musician should be able to play fluidly in all keys, and to hear that these players were impressed by Tristano's emphasis upon these rudiments perhaps seems naive. However, one should bear in mind that in the 1940s acquisition of such a thorough musical education was still largely the domain of conservatory training in western art music. From a practical standpoint, such professionalism was not often required to make a living playing in a majority of the contemporary dancebands, and it is worth remembering that the transposition of standards and blues progressions into the less obvious keys was one of the early barriers to bebop for many players. Such skills were hardly taken for granted in the mid1940s, and the ability to improvise at rapid tempos and in unusual keys was both a hallmark of bebop proficiency, and a popular way to limit access at jam sessions. Marsh explains what he gleaned from the musical correspondence between Tristano and Ferrara:

They were lessons, and they seemed exactly what I wanted from a teacher ... Oh, it was elementary. It was what a musician needs to know to be able to express himself in the language of music ... It was all the rudiments of music that actually you don't get when you go after playing dance band music and playing solos they way kids do. You don't get what classical music does offer if you stay with it long enough, which is polyrhythms and mixed meters and good harmony and ear training, the substance of music. (Chamberlain 2000, 43)

\footnotetext{
${ }^{30}$ Conducting lessons through the mail was an approach often adopted by both Tristano and Konitz when face to face lessons weren't possible. I'm not sure how Tristano managed the logistics of it as early as the late 1940s, but later on both he and Konitz would require their students to send audio cassettes of their playing in order to make suggestions and alterations to the study plan.

${ }^{31}$ With Konitz, Marsh would go on to be one of Tristano's most famous students. In many ways, he may also be considered on of the 'purest' examples of improvising in this tradition.

${ }^{32}$ According to Marsh, his exposure to Lester Young did not come until 1947 when he was transferred to a New Jersey base and began studying with Tristano (Chamberlain 2000, 42).
} 
At the time, the army had a policy under which a draftee with at least one year's active service who could prove that they were going back to school could apply for an honorable discharge. Brown took advantage of this provision and was discharged in February 1947, enrolling at the City College of Long Beach, California, to study chromatic harmony, counterpoint, French, and English. Brown made musical connections, and was soon playing gigs around campus with a quintet and sitting in regularly at sessions in San Pedro, Hollywood, and Los Angeles.

Dexter Gordon and Wardell Gray were very big in L.A. at that time and they certainly had an influence on me. I started going every Wednesday night to the Down Beat Club on Central Ave in L.A. (which later became known as Watts) and usually played with Teddy Edwards and Sonny Criss. Then we would go up the street to an after hours club called Jack's Basket to hear Dexter and Wardell and some of the guys in town from Dizzy Gillespie's big band. Everyone was trying to play the latest Bird tunes and it became a contest after a while. I had all the records at home so if they called a tune I didn't know I would make sure I learned it before the following week. The Musician's Union called for a national recording ban as of January 1, 1948. By the middle of 1948 there were no new Bird or Diz records coming out to the West Coast and we were all wondering what the cats in New York were up to because that's where it was all originating from. (Brown January 17, 2009)

Despite his active playing schedule, Brown was determined to return to New York and the musical activity he had seen and heard on 52nd Street. In 1947, he moved back in with his parents in Long Beach as a way to save money, and put in for his transfer from the Los Angeles A.F.M local ${ }^{33}$ to the New York local, a process which took six months. At the same time, an attempt to use the G.I. bill to further his New York ambitions proved difficult.

I was trying to figure out how to make use of the G.I. Bill and decided I would try to get into Julliard in New York ... which meant I had to audition on clarinet because they were strictly classical at that time and didn't accept saxophone players. I started studying in Hollywood with the first chair clarinetist for the L.A. Philharmonic ... Kalman Bloch. He had me working from an exercise book as well as 5 or 6 pieces he knew were required for the audition. I stopped playing my tenor completely and worked on that material for 3 to 4 hours a day for about 9 months ... into the fall of 1947 . He was really trying to get me in shape with a classical

\footnotetext{
${ }^{33}$ American Federation of Musicians.
} 
tone and the precise classical phrasing for each of those pieces. But finally after all that, he knew my heart just wasn't in it and that I wanted to play jazz. He respected that and advised me to forget about Julliard ... so I stopped ... and a couple weeks later got a call to sub one night on my tenor and ended up working 6 nights a week at a club on the waterfront in Long Beach called The House of Rhythm. (Brown March 31, 2009)

Brown's father had also just been discharged from the army, and at the age of 42 was having difficulty finding work in the airline industry despite his wartime experience. In contrast Ted, just twenty years old, was both collecting a year's worth of "the Army version of unemployment checks" (Brown October 6,2008 ) and playing regularly. Consequently, Ted's earnings were put toward the upkeep of the family home and his plans for saving money for a return to New York were severely hampered.

When I was down to my last 2 checks I realized I would have to get some sort of full time job. So I said, screw it, if I have to do that I would rather be in New York than Long Beach. My father said he could get me a free ride on "standby" on one of the non-scheduled flights and I could also get a ride back if I needed it. I said I would go for 6 months and if it didn't work out I would come back. I didn't go home for 8 years. So in Sept 1948 I left with $\$ 35$ in my pocket. The first night I paid $\$ 5$ for a room at The Lincoln Hotel (now the Milford Plaza) and then hooked up with some friends for a week or so. I hocked my Selmer clarinet for $\$ 40$ and had to get a full time job right away. I started working as a salesman for the Christmas Season, expecting it to end at Christmas, but they liked my work and kept me on for 3 years...transferring me to the inventory control section ... which came in handy many years later when I got into computer programming and had to write programs to do that work. (Brown October 6, 2008)

On Brown's first night in New York he went to the Royal Roost which was featuring the Miles Davis Nonet, which included Lee Konitz. ${ }^{34}$ Ted was struck by Konitz, "his choice of notes, his clean sound, his use of unusual intervals" (Hamilton, 2007: 35), but didn't yet know that Konitz was studying with Tristano.

Brown's army associate Bob Stacy had moved to New York following his enlistment to continue his studies with Tristano, and for a short while Brown stayed with him while looking for his own place. A few weeks after Brown's

${ }^{34}$ Later known as the Birth of the Cool, the band was playing what would turn out to be their only live engagement. 
arrival in New York, Warne Marsh arrived with the Buddy Rich band, and Stacy arranged an invitation for Brown to attend a private session with Konitz, Marsh, and Tristano. The session solidified Brown's interest in Tristano, and he decided to study with him. It was Tristano's habit to interview all prospective students, and once again it was Bob Stacy who arranged the meeting for Brown.

I was very impressed with Lennie but I was very quiet. In fact Bob Stacy later told me Lennie didn't think I would be coming back. But actually I was just convinced I had finally found the right person and just wanted to hear him talk. He sounded like he knew exactly what I needed. Also, I was impressed with how cool he was even though he was blind. In fact he was so sure of himself that after a few minutes I almost forgot he was blind. He said he was only taking students who could be consistent for at least a year. He wasn't interested in anyone who took a few lessons, then went on the road for 6 months, then came back for a few more. I told him I had worked a lot with records and had been playing quite a bit in L.A. and had recently started a day gig here in New York. He thought that was fine and that I would be better off doing that and getting into a long stretch of consistent practice. He talked a little about covering all the basics...scales, chords, ear training, etc. He also said if you missed a lesson you still had to pay for it ... but you could make it up if you wanted to. I made an appointment to start the following week (Brown October 6, 2008).

One of the most distinguishing characteristics of Tristano's pedagogical approach was the sheer amount of time required to absorb and make use of the materials. In terms of acquiring a kind of professional competence for commercial jazz work there were and are much faster and more efficient models. ${ }^{35}$ But Tristano's methodology had precious little to do with the development of employable skills; it was bent on artistic development, and artistic development takes time. In discussing the music of these players, Canadian saxophonist Mike Murley noted,

There's an integrity to the line that's number one ... to the line you're playing and [to] not compromising, not falling into cliches ... and that's where the delicacy comes in because you're living on this very fine edge.

\footnotetext{
${ }^{35}$ This is perhaps the chief reason that the chord/scale approach dominates most of the literature in jazz education (method books, etc), and is the most popular approach in colleges and schools. It is simply faster to develop professional competence using chord / scale methods, and can be tested relatively easily even when dealing with large groups of students.
} 
You have to be. With sound, and with your approach. Of course it's hard. You have to study for so long to be able to do that ...whereas most people [don't want to take the time]. (Murley March 17, 2009)

Tristano was well aware that his approach took an immense amount of time, focus, and a commitment to certain artistic ideals that made earning a living through music somewhat problematic. The encouragement Tristano gave Ted Brown with regard to having a day-job was not unusual (Shim 2007) advice, and many of Tristano's students worked alternate careers while continuing their studies. Though Brown admits to wishing that he could have spent more time focusing solely on his music, he also allows that the financial stability offered by regular work had advantages for one pursuing an artistic, rather than commercial approach to musical development.

When I first arrived in New York City I was 20 years old and was so happy to just be here that having a day gig just didn't bother me. If I hadn't moved here I would have had to work a day gig in California and I couldn't stand the thought of doing that ... I don't have any regrets about working a day job. Yes, it would have been nice to spend more time with music ... but that works both ways. There have been times when events in my personal life were causing me a certain amount of stress and then Monday morning would come and I would be glad to go to work just to have something else to do to change the scene. There have also been times when I was out of work and, believe me, playing my horn was the last thing on my mind if I was worrying about paying the rent.

Jazz history contains several key examples of artists practicing nearly incessantly, and the idea that a jazz student ought to spend more time in the practice room than anywhere else is now something of a truism in certain circles. ${ }^{36}$ Yet Ted Brown provides evidence that it is of course not the quantity of practice that counts, but rather the quality of that practice.

When I started studying with Lennie in November of 1948 I was working a day gig, so from Monday through Friday my practice time had to be at night $\ldots$ and that was usually an hour and a half to two hours. It was very hard to find places to live which would allow me to practice at night. I had a room on 58th Street near Columbus Circle for a while and the

\footnotetext{
${ }^{36}$ The mythology surrounding Charlie Parker, Sonny Rollins and John Coltrane for instance has, I believe, had a significant effect in this regard. Certainly my experience at a college-based jazz program included a great deal of emphasis and posturing surrounding the amount of time spent practicing, and the critically acclaimed film Whiplash (2014) may have served to reenforce this sort of (mis)understanding in the popular perception of jazz training.
} 
Superintendent told me I had to stop at 9:00 PM. By the time I got home from work and had something to eat it would be around 7:00 PM before I could get started. And if I went one minute past 9:00PM the Super would start banging on the radiator. I moved quite often because of noise complaints but eventually found places on the upper west side of Manhattan which would let me play until 10:00 PM. (Brown March 31, 2009)

That Ted only practiced his saxophone for a few hours a night does not at first seem like much, but as Ted was quick to point out "... $11 / 2$ to 2 hours is a lot of time if you plan it properly" (Brown April 24, 2009). The time Brown spent actually playing his saxophone also constituted only one small part of his daily musical practice, the rest of which dealt with concerns not specific to the saxophone, and was often conducted through a process of silent, concentrated mental practice. Tristano's emphasis upon improvisation and melodic development over learned materials lends itself particularly well to forms of practice that do not involve use of the instrument, and Tristano encouraged the development of such techniques.

Perhaps most famously, Tristano placed great emphasis upon the learning of recorded solos. Unlike many common approaches to transcription however, Tristano conceived of the process as being driven by an aural and embodied understanding of the solo, and placed relatively little emphasis on committing the solo to paper. The first step under Tristano was to learn to the sing the solo along with the record, perfectly replicating tone, timbre, time feel, and expression until the singing of the solo became an embodied process. This was then tested by being able to sing the solo without the aid of the recording, again matching perfectly all the elements of musical nuance. The next step was then to learn to play the solo, both independently of the recording and in perfect unison with the recording. Only once all of these steps were complete did the student commit the solo to paper for further analysis, and celebrated pianist Sal Mosca recalled that it took him almost two years to successfully complete the initial steps of his first transcription for Tristano (Shim 2007, 136). Once past the initial stages of singing along with the recording, a student could do a great deal of work on transcriptions away from their instrument. The solo was recalled silently in the mind, and the student worked to be able to hear vividly all of the musical nuances; "singing" along with the solo in their musical imagination. Next, one could sing the solo out loud, working on accurate pitch and rhythmic delivery just about anywhere. Later, processes of visualization would help link the solo to its location on the student's instrument. ${ }^{37}$

${ }^{37}$ Of course MP3 technology has now rendered the entire process portable. 
Learning solos, playing exercises through the keys, exploring harmony, learning tunes, and the actual act of improvising were all construed (to a greater and lesser degree) as aural projects rather than as problems to be solved intellectually. Ear training formed a large component of training with Trista$n^{38}$ as improvisation was meant to be an intuitive, reactive experience rather than a mechanical process. The idea was to train oneself to compose in the moment and of the moment, as free as humanly possible from pre-planning. An analogy has often been made to the use of spoken language; those who have studied more deeply generally have a larger vocabulary and more interesting things to say, but by and large, the use of that vocabulary is intuitive. Musically speaking, we can only improvise what we can "hear," and a concentrated study of ear training is the only way to develop one's vocabulary.

Except for working with records, I did most of my ear training on my lunch hour. Fortunately, in those days I had the luxury of a whole hour for lunch and found places that were quiet so I could hear it in my head and sing it or whistle it softly to myself. Eventually I was able to work on some of the lines in my head as well. (Brown March 31, 2009)

In addition to working with intervals and triads on his lunch break, Brown would use the time spent on subways rides and breaks at work to learn the tunes which he would be expected to be able to play at the weekly sessions held at Tristano's studio.

I also tried to learn the chord progressions to the tunes I would be running into at sessions, so I asked Lennie every week for the changes to another tune. I kept them in a little $3 \times 5$ notebook and during my lunch hour or riding the subway to and from work would sing them to myself while trying to memorize the progression. Then when I got home at night I would spend maybe 20 minutes or so working on one of those tunes. (Brown March 31, 2009)

If I was on the subway or on my lunch hour I would sing the roots ... mainly to memorize the overall progression. At the same time I would say the name of the chord and know what that chord symbol represented. Later at night I would use my horn to play the notes in each chord to be sure I knew what they sounded like. Then I would also try some short melodic phrases using chord tones and scale tones to see how a melody

\footnotetext{
${ }^{38}$ Unlike current academic models, ear training under this method took years to complete. Brown recalls working on simple intervals for months, then triads for months and only later moving on to more advanced types of chords and extensions. Ear training formed a weekly part of his lessons with Tristano for at least two years.
} 
could flow through the progression. Then, over time, I would try to get away from the names of the chords and just try to use my ear to hear the progression. I don't like to play on chord changes. It is too distracting. So after I learn a tune and play it for a while I try to forget about the changes and just concentrate on where my melodic line is going. I read an interview where Pres said, "Don't tell me that is a D7 because then I will only be able to think of those four notes." (Brown April 24, 2009)

Similarly, Tristano stressed the advantages to practicing one's instrument silently, concentrating on hearing the pitches internally and relating them to the appropriate fingering. A combination of these techniques provided opportunities for Brown to practice when it was otherwise unfeasible, such at late at night, or on breaks while at work.

Lennie talked a lot about being able to visualize and relate it to your instrument, knowing what the fingering would be as well. The effect of that kind of practice is truly amazing in the confidence it gives you. It really imbeds it in your brain so you feel it very strongly. (Brown April 24, 2009)

[He also] used to stress the advantage of doing silent practice on your instrument. He used to do that himself late at night in his apartment using a silent keyboard. I started doing that for a few weeks when I couldn't play because I had surgery for a hernia and it really helped. I got to the point where on my lunch hour I would go up to the mezzanine of an $\mathrm{Au}-$ tomat near work where it was quiet and go thru one of the lines in my head ... very slowly, note by note, interval by interval but hearing it and knowing what the fingering would be ... and that was really very beneficial. Then when it came time to play that line at the Saturday night session at the studio it was like I had practiced it every night. (Brown March $31,2009)$

In addition to ear training, study of harmony, and a thorough examination of the saxophone, a weekly hallmark of Browns's lessons with Tristano were compositional exercises upon the harmonic framework of standard tunes in the jazz repertoire. The idea was to choose a tune with which you were familiar, and to write an alternate melody, or "line" over the chord changes. The goal was not to compose a melody in the traditional sense, ${ }^{39}$ but rather to compose an ideal solo. It was an opportunity to slow down the instantaneous process of

${ }^{39}$ The tunes are largely through-composed and lack standard conventions such as repeated sections, clearly delineated bridge melodies, repeated themes or motifs etc. Two Not One with its repeated A sections is a notable exception. 
improvisation and to explore "the shape of the melodic line...why a certain group of notes would sound great and a very similar group would not. That still mystifies me to this day" (Brown March 31, 2009). If the resulting work was deemed promising, the student would learn to play the piece and would work on it further. Several of these compositional assignments were ultimately recorded, and in turn they have formed the standard repertoire for those pursuing this method of study. Among such tunes as "317 E. 32 St." (Tristano), "Kary's Trance," "Subconsciouslee," (Konitz) and "Background Music," (Marsh) stand Ted Brown's compositions "Smog Eyes," "Featherbed," "DigIt," "Little Quail," and "Jazz of Two Cities" as memorable additions to the canon.

Initially, Ted found he needed his saxophone in hand to successfully visualize the pitches, but as he gained experience and progressed with Tristano's techniques of mental practice and visualization, he began relying on the horn less and less.

I think the more you can do it without the horn the better the results are. It helps to avoid certain little licks or favorite tricks that we may not even know we use (Brown April 24, 2009) .... Doing that consistently really helped my playing more than anything else. (Brown March 31, 2009)

As with every aspect of Tristano's method, these compositional techniques and approaches were designed to further develop the skills required by the rigors of improvising.

... just the process of putting it down on paper forces you to listen to that inner voice that is going on in your head, like when you feel like singing or whistling. And getting that first phrase down on paper is the hardest one because that can set a direction for what comes after it. So it might take 15 or 20 minutes hearing different possibilities, playing or singing them, softly so as not to disturb that inner voice, writing them down, changing them or erasing them and deciding whether you like them or not. After you finally decide on that first 3, 4 or 5 bars ... sit back and listen to it again to see if it feels like it wants to go some place for the next phrase. And keep doing that, keeping yourself open to the feeling that your line naturally wants to go some place. And do that phrase by phrase until you have 32 bars. That is the same exact process you are going through when you are improvising. Trying to relax and listen to that inner voice and allow it to lead you through the tune, phrase by phrase, only it is happening much faster. So writing gives you a way to develop the confidence that you can depend on that voice being there when you need it. And to realize that if it isn't there once in a while, it will come if you 
can just pause and relax for a couple seconds until you hear something.

And if it still doesn't happen just stop! (Brown April 24, 2009)

An important aspect of the association with Tristano was the camaraderie that it engendered. Though they may not have interacted much on a daily basis, there was a sense among Tristano's students that they were united in pursuing something special. A subgroup of an already marginal area of musical expression, Tristano's students found support and inspiration in their teacher, and mutual encouragement through their weekly interactions at the playing sessions Tristano organized at his studio. These sessions ran as a complement to weekly lessons and functioned as a laboratory of sorts, enabling students to develop their improvisational skills with other like-minded players. Organized according to ability level, the Wednesday night session was for less experienced pupils and the Saturday evening session, which featured Konitz and Marsh, was the advanced session. Brown began at the Wednesday night session, though he was eventually moved to the Saturday session at which he played with Warne Marsh on a weekly basis for three years. ${ }^{40}$

Tristano's studio provided space for the sessions, and also housed a small recording studio, in which he often taught lessons while the sessions were ongoing. Students often had their lesson the same night as the session on which they played, a situation which provided Tristano the opportunity to hear what a student was doing in an actual improvising context, and to make comments and suggestion based on what he heard. An added benefit for the students was that once the lessons were complete, Tristano would often play the rest of the session with them. The sense of community which these sessions engendered was an essential element of part of the pedagogical process, and helped one persevere along a course of study that was both long, and not popularly received. ${ }^{41}$

... it is true you have to find a few people with similar interests to keep you going. And a good teacher certainly is important. Lennie always managed to keep me on track. Sometimes when I was having problems with certain relationships I was involved with, I wouldn't practice at all that week. But I would still go to my lesson ... not feeling good, of

\footnotetext{
${ }^{40}$ Konitz was out of town for much of this period with Stan Kenton's Orchestra.

${ }^{41}$ Tristano's methods and music were commonly misunderstood, and stood in stark contrast with the hard bop styles popular through the late 1950s and 1960s. Canadian saxophonist Don Palmer, who studied with Lee Konitz in New York from 1959-1962 and then with Tristano, has spoken to me about the teasing and occasionally hostile comments he would receive from other students and musicians in New York at the time.
} 
course, but by the time I left I felt good again and was determined to stay with it. (Brown March 31, 2009)

I also had some experience with big bands and was on the road when I was 17 and 18 years old and I just didn't think that was ever going to lead to anything. I didn't like big bands because if you got to play more than a couple solos a night that was a big deal ... and most of those were one chorus or less. I also knew that with all that traveling it would be impossible to get serious about improving my playing ... Through the people I met who were also studying with Lennie it was great to know a group of musicians who really wanted to play and keep getting better and better at it. And of course once the studio opened up that also became the focal point of my social life ... he started having two sessions a week ... one on Wednesday night and one on Saturday night. I was on the Wednesday night session the first year and Lee and Warne and sometimes Willie Dennis and Don Ferrara were on Saturday night. In 1952 Lee went with Stan Kenton and Lennie moved me over to Saturday night. And we played every weekend until 1955 when they notified Lennie they were knocking down all those buildings to build the Kips Bay apartment complex. He closed down the studio in 1956. But those weekly sessions, playing with Warne, were what made all the difference for me. If someone called us to play a gig on Saturday night we turned it down ... and they thought we were all weird ... but they had no idea what was happening (Brown March 31, 2009).

Brown returned to Los Angles in September 1956, following the closure of Tristano's studio, and joined fellow Tristano-ites Warne Marsh, Ronnie Ball (piano), Jeff Morton (drums) and bass player Ben Tucker, as the Warne Marsh Quintet. The collaboration resulted in the records Jazz of Two Cities (Imperial 1956) ${ }^{42}$, Modern Jazz Gallery (Kapp 1956), and Free Wheeling (Vanguard 1956), Brown's first album under his own name. However, the club that provided the quintet with a regular weekend gig was sold and the group disbanded in April 1957, prompting Brown's return to New York City. As it turns out, this brief eight-month period between the fall of 1956 and spring of 1957 would be the only time that Brown was able to concentrate solely on his music until 1991, when he retired from his career in computer programming. ${ }^{43}$ Perhaps surpris-

\footnotetext{
${ }^{42}$ This session was variously released as Jazz of Two Cities (Imperial), Winds of Marsh (Imperial), and Intuition (Capitol).

${ }^{43}$ Though Brown was able to concentrate solely on music during this period, the activity of the Warne Marsh Quintet was not what one would call lucrative, and his wife had to take a dayjob to supplement the family income.
} 
ingly un-embittered by this, Brown admits that, "actually, the day job allowed me to be more consistent. I usually got off track when I had no day job because I couldn't focus as well if I was worried about my financial situation" (Brown Jan 17, 2009).

After returning to New York from California, Ted continued to play and participated in a recording session with Lee Konitz in 1959 (Lee Konitz Meets Jimmy Giuffre), but was forced to move to Massachusetts in the early 1960s in order to support his family. Though his musical activity was sporadic during the 1960s and 1970s, Brown remained as active as he could, organizing private sessions and sitting in at clubs when the opportunity presented itself. In the late 1970s he returned to New York, briefly resuming his studies with Tristano and recording an album, Figure and Spirit (1976), with Lee Konitz. In the 1980s, using the vacation hours allotted by his day-job, Brown played several engagements in Europe and recorded two albums for the Criss Cross label-In Good Company (1985) and Free Spirit (1987). In 1999 Brown played a twoweek engagement at Birdland with Lee Konitz, and quickly recorded two albums with him, Dig-It (1999) under his own name, and the Konitz release Sound of Surprise (1999). In the 2000s Brown kept busy playing sessions at Sal Mosca's studio in Mt. Vernon, New York, as well as with frequent collaborator guitarist Steve LaMattina. He recorded two albums for the Steeplechase label Preservation (2002) and Shades of Brown (2007), and toured several times, including a 2009 trip to Japan which resulted in two albums-Ted Brown Live at Pit Inn, Tokyo (Marshmallow 2009) and Ted Brown/Gene DiNovi Live In Yokobama (Marshmallow 2009). In 2012 Brown released Pound Cake (Steeplechase 2012) and Two of a Kind (Bleebop 2012), and in 2014 at the age of 87, continues to play regularly in and around the New York City area.

\section{CONCLUSION}

Amid the mass of jazz scholarship which still concentrates on the most famous architects of the music (Parker, Davis, Coltrane et al) it is all too easy to overlook the contributions of less recorded and commercially successful artists. Ted Brown, tenor saxophonist and former student of pianist / educator Lennie Tristano, is such a player. Never quite as successful or well known as fellow Tristano students Lee Konitz and Warne Marsh, Brown nonetheless participated fully in the musical culture that grew up around Tristano's Manhattan studio. A unique and melodic improviser and composer who contributed several tunes to the Tristano canon, Brown managed to reach the highest levels of jazz performance while simultaneously working a full-time day job. An examination of his musical life lends insight into what Nat Hentoff called 'the 
jazz life,' as well as into the practical application of Tristano's pedagogical methods. A talented artist with a decidedly unique story, Ted Brown serves to remind us that some of the most interesting voices of jazz can be of those few people recognize.

\section{BIBLIOGRAPHY}

Ake, David and Charles Hiroshi Garrett. 2012. Jazz / Not Jazz: The Music and Its Boundaries. Berkeley: University of California Press.

Ake, David. 2010. Jazz Matters: Sound, Place, and Time Since Bebop. Berkeley: Univesity of California Press.

Atkins, E. Taylor. 2001. Blue Nippon: Authenticating Jazz in Japan. Durham: Duke University Press. ed. 2003. Jazz Planet: Jazz Planet: Transnational Studies of the "Sound of Surprise." Jackson: University of Mississippi.

Bauer, Billy. 1997. Sideman: The Autobiography of Billy Bauer. William H. Bauer, Inc.

Berliner, Paul. 1994. Thinking in Jazz: The Infinite Art of Improvisation. Chicago: University of Chicago Press.

Chamberlain, Safford. 2000. An Unsung Cat: The Life and Music of Warne Marsh. London: Scarecrow Press.

Cornelius, Marcus M. 2002. Out of Nowhere: The Musical Life of Warne Marsh. Mason Australia: Aurora Nova Publishing.

Davis, Francis. 1986. "Character Analysis" in In the Moment: Jazz in the 1980s. New York: Oxford University Press.

Davis, Francis. 1996. "Tristanoitis" in Bebop and Nothingness: Jazz and Pop at the End of the Century. New York: Schirmer Books.

Evans, Bill. "Compendium of Jazz Quotes" in doublebassblog.org. http://doublebassblog.org/2008/02/compendium-of-jazz-quotes-bill-evans.html (accessed May 1, 2009)

Gardner, Mark. 1999. Dig-It. CD liner notes. Denmark: SteepleChase. 1987. Free Spirit. CD liner notes. Denmark: SteepleChase. 2007. Shades of Brown. CD liner notes. Denmark: SteepleChase.

Giddins, Gary. 1997. “Teddy Wilson, Lennie Tristano and Bill Evans.” Coda 283: 12-17 
Gitler, Ira. 2001. The Master's of Bebop: A Listener's Guide. New York: Da Capo Press.

Hamilton, Andy. 2007. Lee Konitz: Conversations on the Improviser's Art. Ann Arbour: University of Michigan Press.

Hentoff, Nat. 1956. Free Wheeling. CD liner notes. New York: Vanguard Recording Society Inc.

Ind, Peter. 2005. Jazz Visions: Lennie Tristano and His Legacy. London: Equinox.

Iverson, Ethan. 2008. "A Note on Tristano from Stanley Crouch" in DO THE MATH: the bad plus blog and webzine. http://thebadplus.typepad.com/dothemath/2008/05/a-note-on-trist.html (accessed April 18, 2009)

. 2008. "Lennie Tristano/Barak Obama" in DO THE MATH: the bad plus blog and webzine. http://thebadplus.typepad.com/dothemath/2008/05/lennietristano.html (accessed April 18, 2009)

Jago, Marian. 2015. "Jedi Mind Tricks: Lennie Tristano \& Mental Approaches for the Practice of Jazz Improvisation” in Jazz Research Journal. (forthcoming 2015)

. 2013. "What is a Jazz Record Anyway? Lennie Tristano and the Use of Extended Studio Techniques in Jazz" in Journal of the Art of Record Production. Issue 8.

. 2011."Musical Koryu: Lineal Traditions in Jazz: Lennie Tristano / Lee Konitz." in MUSICultures, Vol. 38, p205-227.

McKay, George. 2005. Circular Breathing: The Cultural Politics of Jazz in Britain. Durham: Duke University Press.

McKinney, John Francis. 1978. “The Pedagogy of Lennie Tristano.” EdD. diss., Fairleigh Dickinson University.

Pujol, Jordi. 2003. Jazz of Two Cities: Complete 1956-1957 Sessions. CD liner notes. Spain: Fresh Sound Records.

Shim, Eunmi. 2007. Lennie Tristano: His Life in Music. Ann Arbour: University of Michigan Press.

Stewart Alex. 2007. Making the Scene: Contemporary New York City Big Band Jazz. Berkeley: University of California Press.

Van der Leij, Joop, comp. 2007. Discography of Ted Brown. Unpublished. 


\section{INTERVIEWS}

Brown, Ted. Email correspondence October 5, 2008, October 6, 2008, December 14, 2008, December 17, 2008, January 19, 2009, April 14, 2009 \& April 15, 2009.

Murley, Mike. March 17, 2009 in person interview, Toronto, ON.

\section{About The Contributor}

MARIAN JAGO holds a $\mathrm{PhD}$ in Ethnomusicology from York University in Toronto, Canada. She has published on the lineal traditions and pedagogical practices of Lennie Tristano and Lee Konitz, which whom she studied for several years, and her work on jazz co-operatives in Canada during the 1950s and 1960s is forthcoming from the University of British Columbia press. Her current research interests include improvisation, sound ecology, the relationship of music to landscape, regional forms of jazz expression, ethnography, new forms of musical consumption, and popular culture.

The Journal of Jazz Studies (JJS) is published by the Institute of Jazz Studies at the Newark campus of Rutgers, The State University of New Jersey. JJS is hosted online by the Rutgers University Libraries at http://jjs.libraries.rutgers.edu. 